LAPORAN KASUS

\title{
Peran Plasmafaresis pada Terapi Pasien Sepsis dengan Myasthenia Gravis
}

\section{The Role Of Plasmapheresis In Myasthenia Gravis With Sepsis}

\author{
Ahmad Imron $\bowtie *$, Dita Aditianingsih**, Yohanes W George ** \\ * Bagian Anestesi dan Terapi Intensif Rumah Sakit Mitra Keluarga Bekasi \\ **Bagian Anestesi dan Terapi intensif Fakultas Kedokteran Universitas Indonesia \\ $\triangle$ Korespondensi/correspondence: ahmad_imron@yahoo.com
}

\section{ABSTRACT}

Background: Plasmapheresis is potential to remove harmful or toxic mediator from the circulation. Plasmapheresis have been showed significantly improve outcome in autoimmune disease. The theurapetic efficacy and safety of plasmapheresis in the treatment of the patient in the severe sepsis and septic shock have been studied.

Case: A 18 years old female was diagnosed after respiratory failure due to myasthenia gravis and severe sepsis due to pneumonia. She was referred from other hospital after the failure of anticholinesterase drugs to treat the symptomp of myasthenia gravis. Chest $x$-ray showed infiltrates at paracardial and basal right lung. Therapy had been given during the ICU stay are antibiotic, supportive drugs, and plasmapheresis was performed for 4 times. After appropiate antibiotic had given and plasmapheresis had been performed, the patient showed improvement of the musclestrength. PatienT successfully weaned from ventilator at day-9, and return to the ward at day-10.

Summary: Plasmapheresis plays important role in the treatment of myasthenia gravis with sepsis. Plasmapheresis is utilized to remove a variety of offending plasma pathogens, such as antibodies, abnormal immunoglobulins and circulating immune complexes

Keywords: Myasthenia gravis, plasmapharesis, intensive care

\section{ABSTRAK}

Pendahuluan : Plasmapheresis berpotensi untuk menghilangkan mediator berbahaya atau beracun dari sirkulasi. Plasmapheresis telah menunjukkan peningkatan keluaran yang bermakna pada penyakit autoimun. Kemanjuran theurapetic dan keamanan plasmapheresis dalam pengobatan pasien di sepsis berat dan syok septik telah dipelajari .

Kasus : Seorang perempuan berusia 18 tahun didiagnosis dengan gagal nafas karena myasthenia gravis dan sepsis berat akibat pneumonia. Dia dirujuk dari rumah sakit lain setelah kegagalan obat antikolinesterase untuk mengobati gejala dari myasthenia gravis. $x$ foto thorax menunjukkan infiltrat di paru-paru kanan paracardial dan basal. Terapi yang diberikan selama di ICU adalah antibiotik, obat-obatan suportif, dan plasmapheresis dilakukan selama 4 kali. Setelah antibiotik yang sesuai diberikan dan plasmapheresis selesai, pasien menunjukkan perbaikan kekuatan otot. Pasien berhasil disapih dari ventilator pada hari ke - 9, dan kembali ke bangsal di hari - 10 . 
Ringkasan : Plasmapheresis memainkan peran penting dalam pengobatan myasthenia gravis dengan sepsis. Plasmapheresis digunakan untuk menghapus berbagai faktor pemicu dalam plasma, seperti antibodi, imunoglobulin abnormal dan kompleks imun dalam sirkulasi

Kata Kunci: Myasthenia gravis, plasmapharesis, terapi intensif

\section{PENDAHULUAN}

Banyak perkembangan yang terjadi dalam bidang teknologi medis dan obatobat an baru, tetapi kita tetap menghadapi penyakit yang tidak dapat dikelola dengan baik. Sudah diketahui bahwa auto antibodi dan kompleks imun memainkan peranan dalam penyakit autoimmune. Menghilangkan substansi patogendari plasma diketahui merupakan cara yang efektif dalam terapinya. 1

Teknologi plasmaferesis sudah sangat berkembang dalam 40 tahun terakhir. Plasmapheresis merupakan suatu tindakan mengeluarkan darah dari tubuh, memisahkan bagian sel dengan cara sentrifugasi, dan direinfuskan kembali dengan pengganti plasma. Plasmaferesis digunakan untuk menghilangkan penyebab patogen dalam plasma, seperti antibodi, imunoglobulin abnormal, circulating immune complexes (CICs), cryoprecipitable protein seperti cryoglobulin, low-density lipoprotein (LDL), faktor koagulasi abnormal dan circulating protein-bound toxic agents. Agen patogen ini berpotensi menyebabkan komplkasi seperti gagal ginjal, gangguan saraf, gangguan hematologidan gagal multi organ.2
Myasthenia gravis (MG) merupakan penyakit autoimmune dengan gejala murni pada motorik yang menyebabkan kelemahan dan kelelahan. Gejalanya berfluktuatif sepanjang hari. Penyakit ini dapat mengenai seluruh tubuh atau sebagian saja dan tidak selalu simetris. Gejala pada pernafasan dan mata mengindikasikan beratnya penyakit. 3

Krisis dapat terjadi karena infeksi dalam konteks pemakaian immunosupresan, dosis tinggi pemakaian steroid atau karena terapi yang tidak adekuat. Krisis mengenai otot-otot pernafasan, menyebakan gagal nafas dan memerlukan bantuan ventilasi invasif atau non invasif. Plasmaferesis dan IVIg sering efektif memperbaiki kondisi ini degan latar belakang peningkatan immunosupresan dan optimalisasi acetylcholine esterase inhibitor.4

\section{KASUS}

Wanita 18 tahun, tujuh hari sebelum masuk rumah sakit saat tidur, pasien didapati ibunya mengalami kemerahan pada daerah wajah, 2 jam kemudian ibunya memberikan mestinon tapi saat akan diberikan posisi mulut pasien kaku terkunci, kemudian oleh dokter umum diberikan suntikan prostigmin, kaku 
menghilang, diberikan mestinon, kondisi pasien membaik. Beberapa jam kemudian pasien kembali mengalami kaku-kaku, dibawa ke RS I, diberi injeksi prostigmin, kemudian pasien kaku lagi, diberi prostigmin dan dirujuk ke RS II untuk fasilitas ventilator. Di RS II dirawat selama 7 hari, kaku tidak ada lagi, dengan terapi obat tidak ada perbaikan. Dirujuk ke RS kami untuk plasmafaresis.Ditemukan hipersalivasi $(+)$, diare (-), kelopak mata turun (-), sesak nafas $(+)$, kelemahan tangan kaki $(-)$.

Terdiagnosis myasthenia gravis sejak 3 tahun yang lalu, terapi selama ini dengan mestinon 3 X $60 \mathrm{mg}$. Pasien bisa beraktifitas normal namun terbatas. Hasil CT Thorax sebelum masuk RS menunjukkan gambaran timoma, pasien pernah dianjurkan operasi tapi menolak. Riwayat keluarga tidak ada yang menderita myasthenia, ataupun keluhan serupa.

Pemeriksaan fisik pada hari pertama masuk ICU keadaan umum pasien gelisah namun sadar, TD 110 - 150/70 90 mmHg , N 70 - 120 x/ menit, RR 20 30x/menit. Pemeriksaan fisik paru paru didapatkan ronki pada kedua lapangan paru. Pasien mendapatkan bantuan nafas dengan ventilator dengan setting pressure control PC 12 PEEP 5 RR 10 $\mathrm{FiO} 2$ 60\%. Hasil pemeriksaan laboratorium awal masuk ICU menunjukkan Kadar $\mathrm{Hb}$ 14,9, Hematokrit 46\%, Leukosit 15.800, dan trombosit240.000 dengan $\mathrm{Ca}$ ion 1,08 mEq/L, CRP 168 , Natrium 143mEq/L,
Kalium 4,59 mEq/L, dan Chlorida 108 $\mathrm{mEq} / \mathrm{L}$.

Hasil AGD pada saat masuk ICU menunjukkan $\mathrm{pH}$ 7,32, $\mathrm{paCO} 2$ 38,9, paO2 196, HCO3 20,4 dan $\mathrm{SaO} 2$ 99,2 dengan $\mathrm{x}$-foto thorax menunjukkan massa mediastinal anterior, konsolidasi di paru kanan bawah, infiltrat paracardial kanan

Pasien didagnosis dengan Myasthenia gravis dengan krisis myastenik dan Hospital Acquired Pneumonia. Pasien kemudian mendapat program terapi antibiotik empirik Ceftriaxone 2 x 1 gram dan kultur sputum. FASTHUG bundle dengan diet cair, analgetik morfin ,sedasi midazolam, Tromboembolic prophylaxis heparin, Elevation head of bed $30^{\circ}$ dengan alih baring, Stress ulcer prophylaxis omeprazole, dan pengecekan gula darah per 24 jam

Pada hari ke 2 di ICU, pasien sadar, tekanan darah $110 \mathrm{mmHg}-130 \mathrm{mmHg} /$ $70 \mathrm{mmHg}-100 \mathrm{mmHg}$, Nadi 80 - 110x/ menit, S 36,2 - 37,8 C. Pemeriksaan fisik paru masih menunjukkan ronki +/+. Setting ventilator pasien diubah menjadi SIMV dengan Mandatory ventilation 8 PS 10 PEEP 5 FiO2 40\%. Pasien diprogramkan untuk plasmafaresis dan terapi lain dilanjutkan

Pada hari ke 3 di ICU, pasien Sadar, tekanan darah 100-129/70-90, N 80 $100 \mathrm{x} /$ menit, Laju nafas 20-30 x/menit, S 36,7 - 37,8 C. pemeriksaan fisik masih sama dengan hari sebelumnya dan 
setting ventilator tidak diubah. Pasien menjalani plasmafaresis I.

Pada hari ke 4 di ICU TD 90 - 120/ 60 90, N 80 - 100, FN18 - 30 Pemeriksaan Lekosit meningkat hingga 27.000 setting ventilator diubah menjadi SIMV dengan Mandatory ventilation 10 PS 12 PEEP 5 FiO2 40\%. Pasien diprogramkan untuk Plasmafaresis II

Pada hari ke 6 di ICU didapatkan pemeriksaan Lekosit 20.900 dan hasil kultur Isolate 1 : Acetinobacter baumanii dan Isolate 2 : Enterobacter aerogenes. Resisten terhadap ceftriaxone dan sensitif terhadap doripenem, imipenem, meropenem. Antibiotik ceftriaxon dihentikan dan digantikan dengan Imipenem $4 \mathrm{x}$ 500mg. Terapi lain dilanjutkan. Pasien kemudian diprogramkan untuk weaning, dan setting ventilator diubah menjadi SIMV dengan Mandatory ventilation 6 PS 10 PEEP 5 FiO2 40\%.

Pada hari ke tujuh pasien sadar dengan TD 100 - 140/ 60 - 80, N 80 - 120, FN 12 - 28. Pasien masih dalam program weaning dan setting ventilator diubah menjadi spontan PS dengan PS10 PEEP $5 \quad \mathrm{FiO} 2$ 40\%. Terapi lain masih dilanjutkan dan pasien diprogramkan untuk Plasmafaresis III.

Pada hari ke delapan terdapat perbaikan bermakna pada pemeriksaan fisik dan $\mathrm{x}$ foto thorax paru, setting ventilator diubah menjadi CPAP 5 FiO2 $40 \%$. Pasien diekstubasi pada hari ke Sembilan dan diberikan kanul oksigen binasal 3 lpm. Pemeriksaan lekosit juga menunjukkan perbaikan dengan hasil 10.700. Pasien diprogramkan untuk Plasmafaresis IV. Pada hari ke 10, pasien pindah ke ruang rawat biasa

\section{PEMBAHASAN}

Penyakit autoimun myasthenia gravis (MG) merupakan penyakit tersering yang menyerang neuromuscular junction. Autoantibodi dan ditambah deposit dari komplemen mengurangi jumlah nicotinic acetylcholine receptors (AChR) post sinap dan destruksi mikro motor endplate menyebabkan gangguan transmisi neuromuscular. Gejala utama MG adalah kelemahan dan kelelahan otot rangka umumnya dengan distribusi yang spesifik. Kelemahan meningkat dengan aktifitas dan membaik setelah beristirahat

Pasien sudah didiagnosis MG sejak 3 tahun yang lalu dan mendapat mestinon 3 x $60 \mathrm{mg}$. Pasien dapat beraktifitas normal tetapi dibatasi. Tanda utama MG adalah kelelahan dengan aktifitas fisik dan membaik dengan istirahat. Kelemahan akan diperburuk dengan paparan panas, infeksi dan stres. Kelemahan yang berat pada MG dapat menyebabkan disfagi, berkurangnya kemampuan batuk dan berkurangnya kapasitas vital. Kelemahan otot nafas dapat menyebabkan krisis myasthenic yang mengancam nyawa dan membutuhkan ventilasi mekanik dan pemasangan pipa nasogastrik. Hal ini dapat disebabkan infeksi dan obat-obatan tertenti seperti aminoglikosida, obat 
pelumpuh otot, magnesium sulfat, beta bloker dan antibiotik fluroquinolon. ${ }^{5}$

Saat terjadi serangan pertama, mulut pasien mengunci / trismus. Trismus saat ini digunakan untuk mendefinisikan restriksi dari membuka mulut. Gejala trismus pada MG sangat jarang. Kondisi penyakit neurologis seperti MG jarang disebut sebagai penyebab trismus. ${ }^{6}$

Pasien selain menderita myasthenia gravis, juga jatuh dalam keadaan sepsis. Sepsis merupakan suatu Systemic Inflammatory Response Syndrome yang dipicu oleh infeksi. Hal ini ditandai dengan adanya takikardi 100 x/menit, takipnu 20 - $30 \mathrm{x} /$ menit, lekositosis 15.800, hipertermi $38^{\circ} \mathrm{C}$. Pada foto thorax didapatkan infiltrat pada paru kanan bawah dan paracardial kanan. ${ }^{7}$

Clinical Pulmonary Infection Score (CPIS) pasien ini > 6 yang mengindikasikan adanya pnemonia. Terdapat sekresi trakhea, pada foto torak terdapat infiltrat yang terlokalisir, lekositosis > 11.000. Diberikan antibiotik empirik ceftriaxone sambil menunggu hasil kultur sputum. ${ }^{8}$

Krisis dapat terjadi karena infeksi dalam konteks pemakaian immunosupresan, dosis tinggi pemakaian steroid atau karena terapi yang tidak adekuat. Krisis mengenai otot-otot pernafasan, menyebakan gagal nafas dan memerlukan bantuan ventilasi invasif atau non invasif. Plasmaferesis dan intravenous Immune globulin (IVIg) sering efektif memperbaiki kondisi ini degan latar belakang peningkatan immunosupresan dan optimalisasi acetylcholine esterase inhibitor. ${ }^{4}$

Saat ini di Amerika serikat, immunoglobulin digunakan pada banyak penyakit dengan lebih dari $75 \%$ penggunaan untuk penyakit autoimun atau kondisi inflamasi. FDA meyetujui penggunaan terapi imunglobulin pada penyakit tertentu. Penyakit yang disetujui FDA adalah Primary immunodeficiency disease, Chronic lymphocytic leukemia, Pediatric HIV infection, Kawasaki's disease, Allogeneic bone marrow transplantation, Chronic inflammatory demyelinating polyneuropathy, Kidney transplantation involving a recipient with a high antibody titer or an ABO-incompatible donor, Multifocal motor neuropathy, Guillain-Barré syndrome, Relapsingremitting multiple sclerosis,Myasthenia gravis,Refractory polymyositis, Polyradiculoneuropathy, Lambert-Eaton myasthenic syndrome, Opsoclonusmyoclonus, Birdshot retinopathy, Refractory dermatomyositis, Autoimmune hemolytic anemia, Severe anemia associated with parvovirus B19, Autoimmune neutropenia, Neonatal alloimmune thrombocytopenia, HIVassociated thrombocytopenia, Graftversus-host disease, Cytomegalovirus infection or interstitial pneumonia in patients undergoing bone marrow transplantation, Pemphigus vulgaris, Pemphigus foliaceus, Bullous pemphigoid, Mucous-membrane (cicatricial) pemphigoid, Epidermolysis 
bullosa acquisita, Toxic epidermal necrolysis atau Stevens-Johnson syndrome, Necrotizing fasciitis. ${ }^{9}$

Cara kerja IVIg menekan imuno modulari dan efek anti inflamasi masih belum jelas dengan banyaknya jalur imun bawaan dan adaptif. Dengan banyaknya penyakit ,yang mempunyai profil yang berbeda dengan penyakit lainnya, berespon terhadap terapi immunoglobulin maka sulir mengembangkan mekanisme umum untuk mengetahui cara kerjanya. ${ }^{9}$

Mekanisme yang mungkin berhubungan adalah dengan respon terhadap glucocoricoid. Pada sebagian besar penyakit kronis yang dapat diterap dengan IVIG, glucocorticoid umumnya merupakan first-line therapy. Efek anti inflamasi glucocorticoid berperan dalam modulasi intraselular ( menambah atau menghambat) ekspresi gen. Hasilnya, glucocorticoid dapat mengurangi inflamasi pada beberapa tingkatan, termasuk modulasi produksi cytocain dan chemocain, ekspresi adesi molekul dan akumulasi sel inflamasi. ${ }^{9}$

Plasmaferesis merupakan prosedur pemisahan plasma dari komponen darah di luar tubuh dengancara sentigugase atau dengan membrane plasma separator. Tahun 1978 diperkenalkan prosedur plasma exchange. Setelah plasma dipisahkan dari sel, maka diganti dengan koloid sebagai pengganti plasma, atau diproses lebih lanjut melalui membraneplasma fractionator dan dikembalikan ke pasien tanpa perlu cairan pengganti. ${ }^{2}$

Sebagian besar pasien MG dapat distabilkan dalam jangka panjang dengan thymectomy atau pemberian obat simptomatik, kortikosteroid, immunosupresives, immunoglobulins atau monoclonal agents. Krisis myasthenic sebagian besar dapat diatasi dengan plasma exchange. Terapi ini digunakan pada pasien yang sulit distabilkan dengan terapi medikamentosa. ${ }^{10}$

Dalam kondisi sepsis, dilepaskan seluruh molekul efektor dari host, beberapa jelas bertanggung jawab pada sindroma sepsis secara klinis. Hal ini menjelaskan ketika menghambat salah satu mediator yang menyebabkan disfungsi organ tampaknya tidak dapat menurunkan mortalitas pada syok septik. Banyak mediator sepsis yang mungkin belum ditemukan. Plasmaferesis merupakan metoda non-selektif dengan potensi menghilangkan mediator toksik dari sirkulasi. ${ }^{11}$

Pasien mulai disapih sejak hari kedua perawatan. Hari ketiga dilakukan plasmaferesis, pasien belum dapat dilanjutkan penyapihan dari ventilator sampai hari kelima saat plasmaferesis kedua.

Setelah plasmaferesis kedua pasien mulai dapat dilanjutkan penyapihan. Hari keenam lekosit meningkat menjadi 20.900. Hasil kultur sputum tumbuh Acitenobacter baumanni dan 
Enterobacter aerogenes yang resisten terhadap ceftriaxon dan sensitif terhadap doripenem, imipenem dan meropenem. Antibiotik diganti dengan imipenem $4 \mathrm{x}$ 500mg. Setelah diberikan antibiotik yang sesuai, proses penyapihan dapat berlangsung dan dua hari kemudian dapat dilakukan ekstubasi.

Krisis myastenik dapat dipicu oleh infeksi. Infeksi yang belum tertangani akan menghambat proses pemulihan dari MG. Pemberian antibiotik yang tepat akan menyembuhkan infeksinya. Plasmaferesis membantu mempercepat pemulihan dengan membuang antibodi penyebab MG dan mediator yang beran pada sepsis.

\section{RINGKASAN}

Plasmaferesis memainkan peranan yang penting dalam penangan krisis myasthenic yang disertai dengan sepsis. Kemampuannya untuk menghilangkan penyebab patogen dalam plasma, seperti antibodi, imunoglobulin abnormal, circulating immune complexes (CICs) berperan mencegah progresifitas penyakit .

\section{DAFTAR PUSTAKA}

1. Yang KS,Kenpe K, Yamaji K Plasma Adsorption in Critical Care, Ther Apher
2002 6(3):184-188

2. Siami GA,Siami FS. Membrane Plasmapheresis in the United States: a review over the last 20 years. Ther Apher 2000, 5 (4):315-320

3. Gilhus, NE, Autoimmune myasthenia gravis , Expert Rev. Neurother. 9(3), 351-358 (2009)

4. Turner C. A review of myasthenia gravis: Pathogenesis, clinical features and treatmet., Current Anaesthesia \& Critical Care (2007) $18,15-23$

5. Throuth AJ, Dabi A, Solieman N. Myasthenia Gravis: A Review. Autoimmune Diseases Volume 2012, Article ID 874680

6. Simon SS, Challu AP, Chacko RK. Trismus as first presenting complaint in a case of myasthenia gravis. Indian $\mathbf{J}$ Dent Res 2011;22:729-30.

7. Rice TW, Gordon RB. Theurapetic intervention and target on sepsis, Annu. Rev. Med. 2005. 56:225-48

8. American Thoracic Society : Guidelines for the management of adults with hospital acquired, venlator-associated and healthcareassosiated pnemonia. Am J Respir Crit Care Med 2005;171:388-416.

9. Gelfand EW, Intravenous Immune Globulin in Autoimmune and Inflammatory Diseases, N Engl J Med 2012;367:2015-25

10.Blaha M,Pit'ha J,Lanska M. Extracorporeal Immunoglobulin Elimination for the Treatment of Severe Myasthenia Gravis. Jo Biomed Biotechnol. 2010; 2010:419520

11. Mandawat A. Outcome of plasmapharesis in Myasthenia Gravis: delayed therapy is not favorable. Muscle Nerve, 2011Apr;43(4):57884 